Nr 1(64), 2020, s. 233-253

https://doi.org/10.12797/Politeja.17.2020.64.12

\author{
Marcin DĘBICKI ID \\ Uniwersytet Wrocławski \\ marcin.debicki@uwr.edu.pl \\ Radosław ZENDEROWSKI iD \\ Uniwersytet Kardynała Stefana Wyszyńskiego w Warszawie \\ r.zenderowski@uksw.edu.pl
}

\title{
WZORY GRANIC EUROPY ŚRODKOWEJ Z PERSPEKTYWY WIELOKULTUROWEGO WIEDNIA
}

\author{
REMINISCENCJE, PRÓBY, EKSTRAWAGANCJE \\ I ICH SZERSZY KONTEKST
}

ABSTRACT Patterns of Central Europe's Borders from the Perspective of Multicultural Vienna. Reminiscences, Rehearsals, Extravagances, and Their Wider Context The article analyzes the concept of the territorial distribution of Central Europe and the inhabitants of Vienna as a par excellence Central European city. It lays out the findings from material gathered through 173 questionnaires in the form of a map of Europe, upon which the respondents indicated the territorial scope of Central Europe. Surveys were carried out both among Austrians and migrants living in Vienna. The authors point at two distinct trends: (a) the inclusion of individual states and regions into Central Europe, (b) exclusion of individual countries and regions from Central Europe. As a result, there is a picture of Central Europe conceived in positive terms (as a cultural and civilizational entity) as well as a negative one (in opposition to the East and the Balkans). However, the study is a pilot and requires further scientific research using alternative methods and techniques.

Key words: Central Europe, Eastern Europe, Balkans, borders

Słowa kluczowe: Europa Środkowa, Europa Wschodnia, Bałkany, granice 
G ranice Europy Środkowej, ujmowanej jako idea czy też krąg kulturowy, stanowią temat cieszący się niezmiennym, choć w pewnych okresach nieco słabszym, zainteresowaniem badaczy. Popularność tego zagadnienia można wiązać m.in. ze strachem mieszkańców tego regionu przed Wschodem, jak również z ich swoistym kompleksem niższości, które to uczucia miałyby być zniwelowane poprzez umieszczenie własnego państwa po „właściwej”, czyli zachodniej stronie wyobrażonej linii rozdzielającej kontynent na dwa bloki cywilizacyjne. Jednocześnie przypływy uwagi kierowanej w stronę tematu owych granic, kojarzone m.in. z kolejnymi geopolitycznymi wzmożeniami, niejednokrotnie skutkują reprodukcją dotychczas wysuwanych ujęć, nierzadko zresztą wywodzonych z tych samych źródeł. Działania te sprowadzają nad interesujące nas zagadnienie widmo intelektualnej wtórności i spłaszczenia poprzez wrażenie zasklepienia się historii w raz wyznaczonych ramach.

Świadomi tego ryzyka, postanowiliśmy spojrzeć na Europę Środkową od nieco innej strony - odczuć osób, które po pierwsze od kilku/kilkunastu lat albo wręcz od urodzenia żyją w Wiedniu; po drugie po części wywodzą się z (zupełnie) innego kręgu kulturowego; po trzecie sprawami naukowymi (a szczególnie środkowoeuropejskimi) na co dzień się nie zajmują, a raczej w zasadzie nie zajmują się nimi w ogóle, o czym można wnioskować po wykonywanych zawodach (informacja z metryczki). I chociaż przedstawiając szerszy kontekst dla zdiagnozowanego stanu rzeczy, a tym bardziej koncentrując się na delimitacjach mających utrwaloną pozycję w literaturze przedmiotu (czyli na tytułowych reminiscencjach), zaświadczamy o tym, że z owego dominującego modelu analityczno-interpretacyjnego nie zamierzamy uwolnić się całkowicie, to żywimy nadzieję, że przyjęta perspektywa wzbogaci refleksję na interesujący nas temat o próby wyjścia poza znane schematy, a nawet o swego rodzaju ekstrawagancje, które jednakowoż w przyszłości mogą zyskać inną kwalifikację.

Porzucając w tym miejscu na moment rygoryzm językowy, zapytajmy, czymże jest ekstrawagancja w kontekście środkowoeuropejskim, gdzie - jak to zostało kiedyś zgrabnie ujęte - jedyną stałą jest brak stałości. Albo inaczej: czy ekstrawagancją nie jest kolejna próba uporządkowania tej części Europy i wytyczenia jej granic - zewnętrznych i wewnętrznych, swoistych kulturowych enklaw? W takim właśnie duchu wypowiedział się niedawno Ziemowit Szczerek:

Muzyka. Jedzenie. Architektura. Polityka. Wzasadzie trudno powiedzié,, co jest tureckie, a co po prostu lokalne. Batkańskie albo bliskowschodnie. I gdzie kulturowo kończa się Batkany, a zaczyna Bliski Wschód. I czy w ogóle takie rozgraniczenie ma jakikolwiek sens. Na Batkanach bliskowschodniość taczy się środkowoeuropejskościa i wschodnioeuropejskościa. Ta ostatnia z kolei - w krajach battyckich - wtapia się w skandynawskość. A środkowoeuropejskość - w Czechach czy Stowenii - w zachodnioeuropejskość. Tak to jest z ta Europa Srodkowo-Wschodnia. To wieczny korytarz. Wieczna transformacja ${ }^{1}$.

Z. Szczerek, Międzymorze. Podróżeprzez prawdziwa i wyobrażona Europę Środkowa, Warszawa-Wołowiec 2017, s. 188. 


\section{MIEJSCE BADANIA: WIELOKULTUROWY WIEDEŃ W WIELOKULTUROWEJ AUSTRII (WCZORAJ I DZIŚ)}

Miejsce przeprowadzonych badań nie jest przypadkowe. Austria przez kilkaset lat stanowiła wielokulturowe, wieloetniczne i wielowyznaniowe imperium. Dopiero po I wojnie światowej stała się „typowym” państwem narodowym, względnie jednorodnym etnicznie, by od kilkudziesięciu lat na nowo przekształcać się w państwo wielonarodowościowe. Począwszy od XVI w., Austria stanowiła znaczącą siłę polityczną w Europie Środkowej. W 1526 r. niemiecka dynastia Habsburgów władająca Austrią weszła w posiadanie Czech, Węgier i Śląska, a w drugiej połowie XVIII w. - południowych ziem Rzeczypospolitej oraz Bukowiny. Cesarstwo Austrii, powstałe w 1804 r. na bazie Monarchii Habsburgów, będącej związkiem państw w unii personalnej, liczyło sobie niemal 700 tys. $\mathrm{km}^{2}$ i ponad 50 mln mieszkańców (1910). W 1867 r., w wyniku ugody austriacko-węgierskiej, zostało ono przekształcone w dualistyczną monarchię, składającą się z dwóch części (Przedlitawia ze stolicą w Wiedniu i Zalitawia ze stolicą w Budzie/ Budapeszcie), połączonych unią realną pod berłem cesarskiej dynastii Habsburgów. Od 1878 r. Austro-Węgry administrowały Bośnią i Hercegowiną, która została w 1908 r. formalnie przyłączona do państwa austro-węgierskiego. Było to największe państwo Europy Środkowej, które cechowało się wysokim stopniem zróżnicowania etnicznego i wyznaniowego (zob. tabele 1,2). Językiem niemieckim na co dzień posługiwał się zaledwie co czwarty mieszkaniec monarchii, katolicy zaś stanowili ³/4 ogółu mieszkańców.

Tabela 1. Liczebność mieszkańców Austro-Węgier wg deklarowanego języka służącego do codziennych kontaktów (1910/1911)

\begin{tabular}{|c|c|c|}
\hline Język & Liczba użytkowników & \% populacji \\
\hline niemiecki & 12006521 & $23,36 \%$ \\
\hline węgierski & 10056315 & $19,57 \%$ \\
\hline czeski & 6442133 & $12,54 \%$ \\
\hline polski & 4976804 & $9,68 \%$ \\
\hline serbo-chorwacki & 4380891 & $8,52 \%$ \\
\hline rusiński/ukraiński & 3997831 & $7,78 \%$ \\
\hline rumuński & 3224147 & $6,27 \%$ \\
\hline słowacki & 1967970 & $3,83 \%$ \\
\hline słoweński & 1255620 & $2,44 \%$ \\
\hline włoski & 768422 & $1,50 \%$ \\
\hline inny & 2313569 & $4,51 \%$ \\
\hline razem & 51390223 & $100,00 \%$ \\
\hline
\end{tabular}

Źródło: Volkszählung vom 31. Dezember 1910, Geographischer Atlas zur Vaterlandskunde an der osterreichischen Mittelschulen, Wien 1911; W.R. Shepherd, Distribution of Races in Austria-Hungary, Wien 1911. 
Tabela 2. Liczebność mieszkańców Austro-Węgier według deklarowanego wyznania

\begin{tabular}{|c|c|c|c|c|}
\hline Wyznanie & Austro-Węgry & $\begin{array}{c}\text { Przedlitawia } \\
\text { (Austria) }\end{array}$ & $\begin{array}{c}\text { Zalitawia } \\
\text { (Węgry) }\end{array}$ & $\begin{array}{c}\text { Bośnia } \\
\text { i Hercegowina }\end{array}$ \\
\hline katolicy & $76,6 \%$ & $90,9 \%$ & $61,8 \%$ & $22,9 \%$ \\
\hline protestanci & $8,9 \%$ & $2,1 \%$ & $19,0 \%$ & $0,3 \%$ \\
\hline prawosławni & $8,7 \%$ & $2,3 \%$ & $14,3 \%$ & $43,5 \%$ \\
\hline żydzi & $4,4 \%$ & $4,7 \%$ & $4,9 \%$ & $0,6 \%$ \\
\hline muzułmanie & $1,3 \%$ & $0 \%$ & $0 \%$ & $32,7 \%$ \\
\hline
\end{tabular}

Źródło: Volkszählung vom 31. Dezember 1910, Geographischer Atlas zur Vaterlandskunde an der osterreichischen Mittelschulen, Wien 1911; W.R. Shepherd, Distribution of Races in Austria-Hungary, Wien 1911.

Po rozpadzie Austro-Węgier i ustanowieniu Republiki Austrii kraj ten stał się względnie jednorodny etnicznie (podobnie jak Węgry). Zdecydowaną większość mieszkańców stanowiła wówczas ludność niemiecka lub niemieckojęzyczna. Użycie określenia „ludność niemieckojęzyczna” zamiast odwołania do austriackiej kategorii narodowej nie jest przypadkowe. Austriackość jako kategoria narodowa pojawiła się bowiem stosunkowo późno, bo dopiero po II wojnie światowej. Adam Romejko pisze: $Z$ danie austriackiego spoteczeństwa nt. „kim jesteśmy” ewoluowato od postawy postrzegania sie jako Niemców, do powszechnego uznania bycia Austriakami, narodem niezależnym od niemieckiego. W 1965 r., w ramach przeprowadzonych badań, uzyskano nastęujące wyniki: 48\% badanych odpowiedziato, że Austriacy sa jednym narodem; 23\% - Austriacy powoli zaczynaja czuć się narodem; 15\% - Austriacy nie sq narodem. W okresie późniejszym otrzymano odpowiednio wyniki: w 1977 r.: 62\%, 16\%, 11\%; w 1992 r.: 70\%, 15\%, 8\%².

Nie zmienia to faktu, że niemała (trudna jednak do oszacowania) część współczesnych Austriaków posiada inne niż niemieckie korzenie etniczne.

Mając na uwadze współczesną strukturę etniczną Austrii, należy rozróżnić dwie kategorie osób nieidentyfikujących się z austriackością jako kategorią etnokulturową. Mianowicie są to: (a) mniejszości narodowe (Volksgruppen) posiadające określony status w prawie austriackim, których członkowie posiadają obywatelstwo austriackie, (b) obcokrajowcy zamieszkujący Republikę Austrii bez obywatelstwa austriackiego. Jak zauważa Ewa Godlewska, komentując zróżnicowanie etniczne Austrii: $W$ dużej mierze fakt ten wynika z podziatu na tzw. mniejszości autochtoniczne, czy też uznane (anerkannte Minderheiten) oraz naptywowe, a więc nieuznane oficjalnie przez wtadze (unanerkannte Minderheiten). Konsekwencje tego zróżnicowania sa bardzo poważne. Jedynie pierwsza grupa mniejszości korzysta z szerokiego katalogu uprawnieñ ${ }^{3}$.

Liczebność osób należących do uznawanych przez prawo austriackie mniejszości narodowych jest nieporównanie mniejsza od liczby imigrantów, stanowiących obecnie

2 A. Romejko, Przemiany austriackiej tożsamości narodowej, [w:] Procesy migracyjne w kontekście przemian kulturowo-cywilizacyjnych, red. E. Polak, J. Leska-Ślęzak, Pelplin 2007, s. 285.

3 E. Godlewska, Status prawny mniejszości narodowych w Austrii na przetomie XX i XXI wieku, „Forum Politologiczne" 2007, nr 5, s. 177. 
ponad $15 \%$ społeczeństwa austriackiego, przy czym wzrost tego odsetka w ciągu ostatniej dekady jest bardzo wyraźny - z 9,7\% w 2007 do 16,7\% w 2020 r. (zob. wykresy poniżej).

Wykres 1. Odsetek obcokrajowców w Austrii w podziale na grupy narodowościowe (2020)

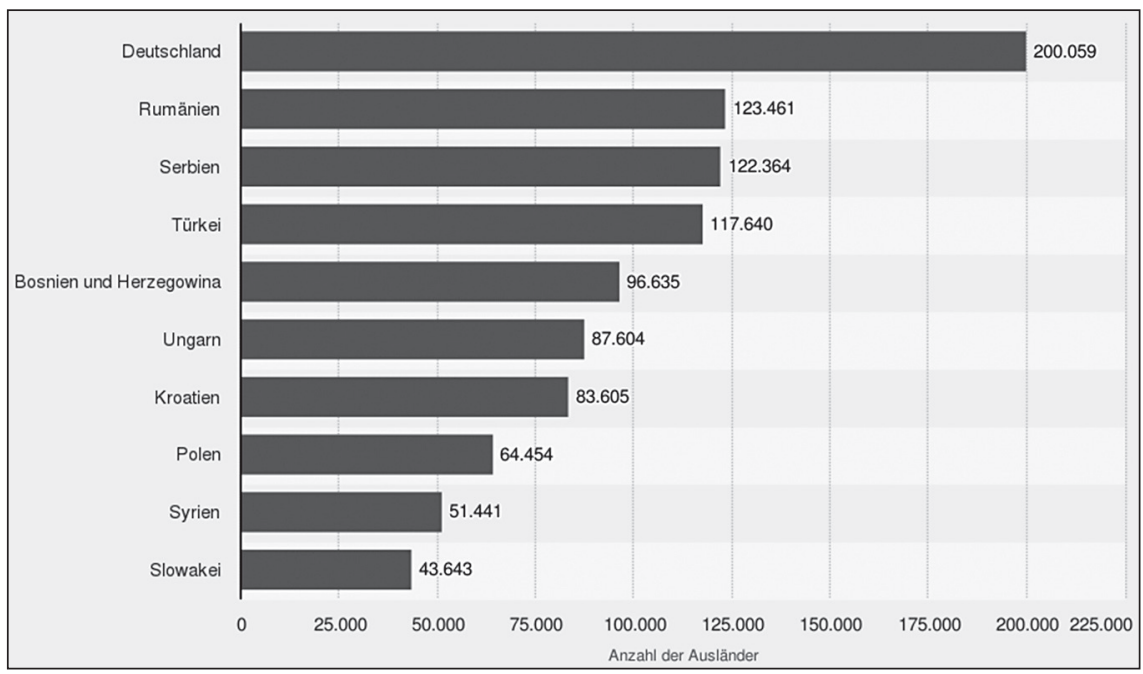

Źródło: Anzabl der Ausländer in Österreich nach den zehnwichtigsten Staatsangehörigkeiten am 1. Januar 2020, [online] https://de.statista.com/statistik/daten/studie/293019/umfrage/auslaender-in-oesterreichnach-staatsangehoerigkeit/, 20 IV 2020.

Wykres 2. Odsetek obcokrajowców w Austrii w latach 2010-2020

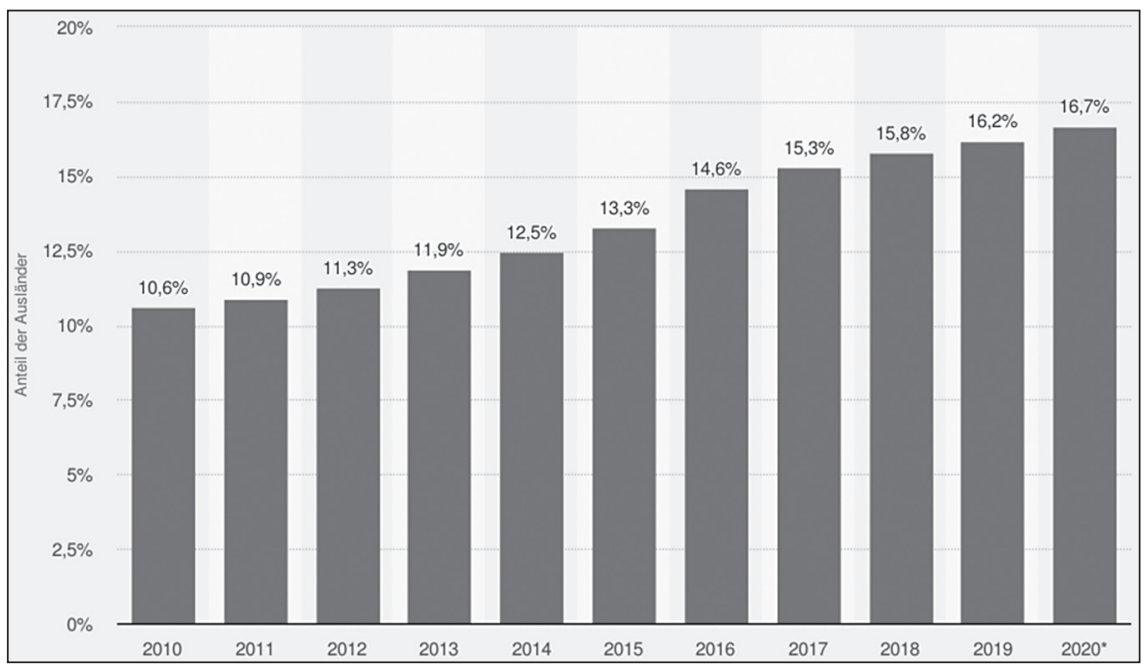

Źródło: Anzahl der Ausländer in Österreich nach den zehnwichtigsten Staatsangehörigkeiten am 1. Januar 2020, [online] https://de.statista.com/statistik/daten/studie/293019/umfrage/auslaender-in-oesterreichnach-staatsangehoerigkeit/, 20 IV 2020. 
Austria, ciesząca się w prawie międzynarodowym specjalnym statusem, po II wojnie światowej - a zwłaszcza po przyjęciu w 1955 r. tzw. traktatu państwowego proklamowanego przez Austrię, Związek Radziecki, Wielką Brytanię, Francję i Stany Zjednoczone - jako państwo o zagwarantowanej w prawie międzynarodowym wieczystej neutralności, stała się atrakcyjnym miejscem migracji, docelowych i przejściowych. Migracje te miały zarówno charakter przymusowy (uchodźczy), jak i ekonomiczny.

Szacuje się, że w okresie zimnej wojny Austria była miejscem schronienia dla ok. $2 \mathrm{mln}$ osób (1/4 jej populacji). Większość uchodźców i emigrantów decydowała się jednak na dalszą podróż. Przykładem mogą być Żydzi z ZSRR i innych państw tzw. bloku państw socjalistycznych. Około 250 tys. członków tego narodu przez pewien czas, w okresie 1973-1989, przebywało tymczasowo na terytorium Austrii. W 1956 r. do kraju nad Dunajem napłynęła fala ok. 180 tys. uciekinierów z Węgier, osób obawiających się represji po stłumionym przez Sowietów powstaniu w Budapeszcie. Ci również w większości rozproszyli się później po poszczególnych krajach Europy Zachodniej, Stanach Zjednoczonych, Kanadzie i innych państwach należących do cywilizacji zachodniej. Do podobnej sytuacji doszło w 1968 r., po wydarzeniach tzw. Praskiej Wiosny. Wówczas do Austrii napłynęło ok. 160 tys. Czechów i Słowaków, którzy - podobnie jak Węgrzy - rozproszyli się następnie po innych państwach Europy i nie tylko. Na początku lat 80 . XX w. nastąpiła z kolei pokaźna emigracja Polaków, uciekających ze swojego kraju w obawie przed represjami w związku z zaangażowaniem w ruch „Solidarności”. Na prawie 35 tys. wniosków o azyl złożonych w 1981 r. przeszło 29 tys. stanowily te podpisane przez polskich obywateli. Szacuje się natomiast, że na terytorium Austrii w pierwszej połowie lat 80. XX w. znalazło się ok. 150 tys. Polaków. Po 1989 r. Austria doświadczyła kolejnej fali migracyjnej, tym razem związanej zwłaszcza z konfliktami zbrojnymi, do których doszło na obszarze byłej Jugosławii. I tak w 1991 r. zamieszkiwało ją prawie 200 tys. obywateli Jugosławii, a 10 lat później - już ponad 320 tys. ${ }^{4}$

Jeśli chodzi o migracje ekonomiczne w okresie tzw. zimnej wojny, należy zwrócić uwagę na porozumienia międzyrządowe z Turcją (1964) oraz Jugosławią (1966), które tworzyły instytucjonalne ramy dla procesu migracji zarobkowej w Austrii. Liczba Turków w Austrii z 211 w 1961 r. wzrosła do 59900 w 1981 r. W przypadku Jugosławii

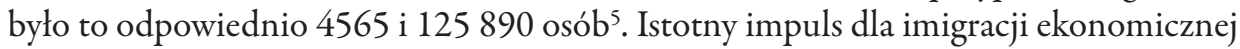
z państw Europy Środkowo-Wschodniej stanowiło przystąpienie części państw regionu do Unii Europejskiej (2004) i Strefy Schengen (2007), a w późniejszym czasie otwarcie rynku pracy dla obywateli nowych państw UE (rząd austriacki otworzył rynek pracy dla obywateli nowych państw UE dopiero w 2011 r.).

Zjawisko migracji dotyczy w pierwszej kolejności Wiednia jako środkowoeuropejskiej metropolii, a jednocześnie najdalej wysuniętej (nie licząc Skandynawii) stolicy

D. Czakon, Od imigracji do integracji po status mniejszości narodowej. Przyktad Polaków w Austrii, „Studia Migracyjne - Przegląd Polonijny” 2011, z. 2, s. 173.

Tamże; P. Findl, H. Helczmanovszki, The Population of Austria. Austrian Academy of Sciences, Institute of Demography. 1974 World Population Year, Vienna 1977, s. 130-134; M. Jandl, A. Kraler, Austria: A Country of Immigration?, Migration Policy Institute, [online] https://www.migrationpolicy.org/ article/austria-country-immigration, 23 X 2017. 
państwa należącego do tzw. starej Unii. Sam Wiedeń - w ujęciu historycznym miasto par excellence środkowoeuropejskie - w niniejszym artykule traktujemy jako przykład metropolii zachodnioeuropejskiej, z jej podstawowym wyróżnikiem na tle Europy Środkowej, czyli brakiem doświadczenia komunizmu typu radzieckiego, a także korelatami tegoż. Za takie uznajemy tu: przynależność (choć w ograniczonym stopniu) Austrii do Europy Zachodniej po 1945 r. (ład zimnowojenny), określony poziom stopy życiowej mieszkańców Wiednia, ich ekspozycję na standardy zachodnioeuropejskie, rosnące zróżnicowanie etniczne populacji miasta, a także jego metropolitarność. Dodajmy, że jakkolwiek ta ostatnia właściwość nie stanowi cechy dystynktywnej ośrodków Europy Zachodniej, niewątpliwie o metropolię w europejskim rozumieniu jest tam dużo łatwiej niż w środkowej czy wschodniej części kontynentu.

Wiedeń stanowi najbardziej zróżnicowaną etnicznie i kulturowo metropolię Europy Środkowej o bardzo wysokim odsetku obcokrajowców, przy czym - w odróżnieniu od Zurychu - owa wielokulturowość wynika w dużej mierze z wielowiekowej historii miasta, będącego stolicą wielonarodowej i wieloreligijnej monarchii. Obecnie (dane z 2011 r.) jedynie nieco więcej niż połowę populacji Wiednia stanowią osoby urodzone w Austrii, posiadające austriackie obywatelstwo i których rodzice także urodzili się w Austrii (niekoniecznie w Wiedniu!). Z drugiej strony młodzi mieszkańcy miasta (w przedziale wiekowym 25-35) urodzeni poza Austrią i nieposiadający obywatelstwa austriackiego stanowią ponad 1/4 populacji (a w skali wszystkich przedziałów wiekowych niemal $1 / 5)^{6}$.

Proces „umiędzynarodowienia” Wiednia poprzez systematyczny wzrost liczby obcokrajowców mieszkających na stałe w tym mieście ilustruje wykres 3. Widać na nim wyraźnie, jak od 1961 r. znacząco zwiększa się odsetek nie-Austriaków (w sensie obywatelstwa austriackiego) w stolicy naddunajskiej republiki. W 1961 r. stanowili oni zaledwie 1,5\%, zaś w 2011 r. już 21,7\%7.

Obecnie w Wiedniu żyje ok. 1,8 mln mieszkańców, przy czym największą liczbę obywateli miasta - prawie 2,1 mln - odnotowano w 1910 r. W'śród nieniemieckich (nieaustriackich ${ }^{8}$ ) mieszkańców miasta dominują „tradycyjne” mniejszości, wywodzące się z krajów należących niegdyś do c.k. monarchii - Chorwaci, Słoweńcy, Rumuni, Węgrzy, Czesi i Słowacy. Do tej kategorii można zaliczyć także Polaków, przy czym większość z nich stanowią imigranci z ostatnich dwóch dekad. Poza wymienionymi narodowościami sporą grupę stanowią Turcy i przedstawiciele narodów bałkańskich (obok wspomnianych już Chorwatów i Słoweńców, których traktuje się w kategoriach mniejszości „tradycyjnych” i chyba bardziej środkowoeuropejskich niż bałkańskich, są to: Serbowie,

6 Monitoring Integration Diversity Vienna 2009-2011. Short version, s. 4, [online] https://www.wien. gv.at/menschen/integration/pdf/monitoring-2012-short.pdf, 2 XI 2014.

7 Census 2011 Wien. Ergebnisse zur Bevölkerung aus der Registerzählung, s. 51, [online] https://www. statistik.at/web_de/dynamic/statistiken/bevoelkerung/volkszaehlungen_registerzaehlungen_abgestimmte_erwerbsstatistik/publdetail ?id=22\&listid=22\&detail=671, 3 XI 2014.

8 Austriackość jako kategoria narodowa utrwaliła się w świadomości społecznej dopiero po II wojnie światowej (w latach 60. i 70. XX w.), wypierając tym samym niemiecką tożsamość narodową. A. Romejko, Przemiany austriackiej tożsamości narodowej..., s. 285. 
Czarnogórcy, Boszniacy, Macedończycy, Albańczycy). Ponadto należy wspomnieć również o ludności romskiej. Niemałą grupę stanowią także Niemcy nieidentyfikujący się $\mathrm{z}$ austriacką kategorią narodowościową. Przemiany struktury etnicznej Wiednia ilustruje zestawienie wyników dwóch spisów powszechnych - z lat $1910 \mathrm{i} 2011$. Z państw należących do UE najliczniejsze grupy imigrantów tworzą Niemcy i Polacy, z kolei w gronie nieunijnych państw pochodzenia dominują Turcy, Serbowie i Boszniacy.

Wykres 3. Mieszkańcy Wiednia z nieaustriackim obywatelstwem (1951-2011)

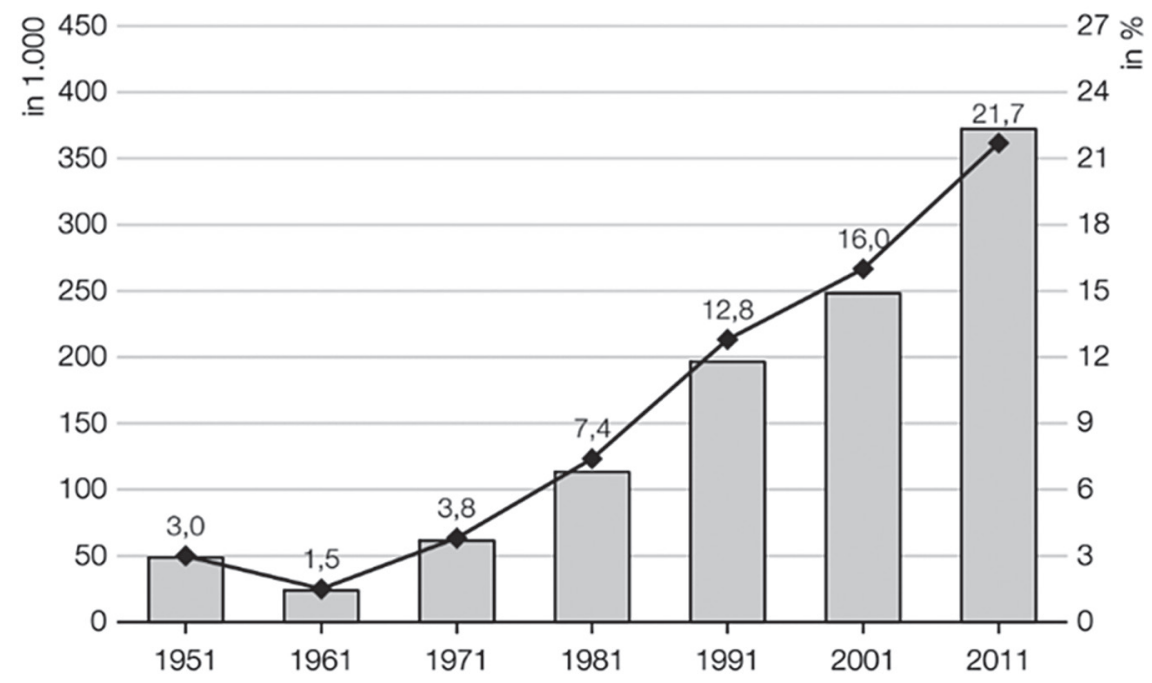

Źródło: Census 2011 Wien. Ergebnisse zur Bevölkerung aus der Registerzählung, s. 51, [online] https:// www.statistik.at/web_de/dynamic/statistiken/bevoelkerung/volkszaehlungen_registerzaehlungen_abgestimmte_erwerbsstatistik/publdetail?id=22\&listid=22\&detail=671,3 XI 2014.

Tabela 3. Struktura etniczna Wiednia w 2013 r.*

\begin{tabular}{|c|c|c|c|}
\hline & Liczba bezw. & \% populacji & $\begin{array}{c}\text { \% populacji } \\
\text { pochodzenia } \\
\text { cudzoziemskiego }\end{array}$ \\
\hline ogół mieszkańców & 1741246 & 100 & --- \\
\hline austriacka ludność autochtoniczna & 1194485 & 69,0 & --- \\
\hline cudzoziemcy & 546761 & 31,0 & --- \\
\hline EUROPA & 439311 & 25,2 & 80,3 \\
\hline państwa UE & 192171 & 11,0 & 35,1 \\
\hline Bułgaria & 10781 & & \\
\hline Republika Czeska & 16193 & & \\
\hline Niemcy & 43980 & & \\
\hline
\end{tabular}




\begin{tabular}{|c|c|c|c|}
\hline & Liczba bezw. & $\%$ populacji & $\begin{array}{c}\% \text { populacji } \\
\text { pochodzenia } \\
\text { cudzoziemskiego }\end{array}$ \\
\hline Hiszpania & 2157 & & \\
\hline Francja & 3885 & & \\
\hline Wielka Brytania i Irlandia Północna & 3480 & & \\
\hline Grecja & 2012 & & \\
\hline Węgry & 16429 & & \\
\hline Włochy & 6022 & & \\
\hline Holandia & 1482 & & \\
\hline Polska & 41217 & & \\
\hline Rumunia & 23110 & & \\
\hline Słowacja & 12808 & & \\
\hline Inne & 8615 & & \\
\hline Państwa spoza UE & 247140 & 14,2 & 45,2 \\
\hline Albania & 1167 & & \\
\hline Bośnia i Hercegowina & 42135 & & \\
\hline Szwajcaria & 3129 & & \\
\hline Chorwacja & 12770 & & \\
\hline Kosowo & 7631 & & \\
\hline Macedonia & 10626 & & \\
\hline Federacja Rosyjska & 14478 & & \\
\hline Serbia i Czarnogóra & 81348 & & \\
\hline Turcja & 66695 & & \\
\hline Ukraina & 4500 & & \\
\hline Inne & 2661 & & \\
\hline AFRYKA & 23149 & 1,3 & 4,2 \\
\hline AZJA & 69878 & 4,0 & 12,8 \\
\hline AMERYKA & 13267 & 0,8 & 2,4 \\
\hline OCEANIA & 961 & 0,1 & 0,2 \\
\hline BEZPAŃSTWOWCY & 0 & & \\
\hline $\begin{array}{l}\text { NIEZADEKLAROWANI, } \\
\text { NIEZNANI }\end{array}$ & 195 & 0,0 & 0,0 \\
\hline
\end{tabular}




\section{ZAŁOŻENIA TEORETYCZNO-METODOLOGICZNE}

Badanie, które stało się punktem wyjścia dla formułowanych przez nas twierdzeń, zostało przeprowadzone w $2016 \mathrm{r}$. w formie ankiety audytoryjnej na próbie 173 osób. Ankietę przeprowadzili, po uprzednim przeszkoleniu, studenci kierunku „stosunki międzynarodowe” Wydziału Zamiejscowego w Wiedniu Górnośląskiej Wyższej Szkoły Handlowej im. Wojciecha Korfantego w Katowicach. Respondentów można przyporządkować do trzech kategorii: (a) obywatele Austrii (niezależnie od pochodzenia etnicznego), (b) obywatele państw tradycyjnie zaliczanych do Europy Środkowej (przede wszystkim Polski, Republiki Czeskiej, Słowacji i Węgier), (c) obywatele państw spoza Europy Środkowej lub w ogóle spoza Europy', przy czym liczebności poszczególnych zbiorów są nierówne, a dwa ostatnie dodatkowo wewnętrznie dość zróżnicowane. Należy podkreślić, że choć czasami, w przypadkach szczególnie interesujących, będziemy nawiązywać do przyjętego podziału, próbę traktujemy przede wszystkim jako zbiór ludzi, których łączy doświadczenie życia w Wiedniu - mieście stanowiącym dla nas w pierwszej kolejności przykład zachodnioeuropejskiej metropolii, choć nie będziemy przy tym unikać nawiązań do „środkowoeuropejskiego” etapu jego przeszłości (więcej na ten piszemy w punkcie poświęconym Wiedniowi). Inaczej mówiąc, interesuje nas poszerzenie spojrzenia na kwestię wzorów delimitacji Europy Środkowej o opinie osób żyjących w realiach wobec niej przynajmniej do pewnego stopnia zewnętrznych, nie zaś doszukiwanie się związków między określonym ujęciem problemu a krajem pochodzenia respondenta.

W związku z tym, że naszym celem było zrekonstruowanie sposobów ujmowania granic Europy Środkowej, badanym przedłożono mapę Europy (zob. rysunek 1) z granicami poszczególnych państw (bez ich nazw) i poproszono, aby wyznaczyli obszar ich zdaniem składający się na Europę Środkową ${ }^{10}$. Technicznie rzecz ujmując, mamy tu więc do czynienia z formą ankiety audytoryjnej zawierającej jedno pytanie wieloalternatywne i z maksymalnym roszczeniem zupełności (badacz prosi o wskazanie wszystkich tych odpowiedzi, które dotycza respondenta $)^{11}$. Co ważne, liczba możliwych kombinacji była w zasadzie nieograniczona (a w każdym razie bardzo duża), z czego badani niejednokrotnie korzystali, proponując nie tylko delimitacje pokrywające się z granicami państw, lecz także takie, które rozdzielały poszczególne organizmy na regiony (z tego powodu w artykule posługujemy się obok pojęcia „państwo” również pojęciami „obszar" lub „ziemie”).

9 Ponadto narzędzie badawcze zawierało pytania metryczkowe: o pochodzenie etniczne respondenta, płeć, wiek, wykonywany zawód oraz długość stażu w Austrii.

10 W dosłownym brzmieniu: Proszęzaznaczyć na mapie obszar Europy Środkowej. Należy dodać, że mapa została opisana jako „Eastern Europe”, a ponieważ obejmuje ona wszystkie państwa „tradycyjnie” ujmowane jako Europa Środkowa, można zastanawiać się nad wpływem owej etykiety. Z brzmieniem pytania łączy się też kwestia tego, że część osób, sama z siebie, nie pomyślałaby o Europie Środkowej jako czymś odrębnym, ale taki scenariusz został im zasugerowany pytaniem.

11 L. Gruszczyński, Kwestionariusze w socjologii. Budowa narzędzi do badań surveyowych, Katowice 1999, s. 41, 48, Skrypty Uniwersytetu Śląsiego, nr 551. 
Rysunek 1. Mapa konturowa Europy przedstawiona respondentom

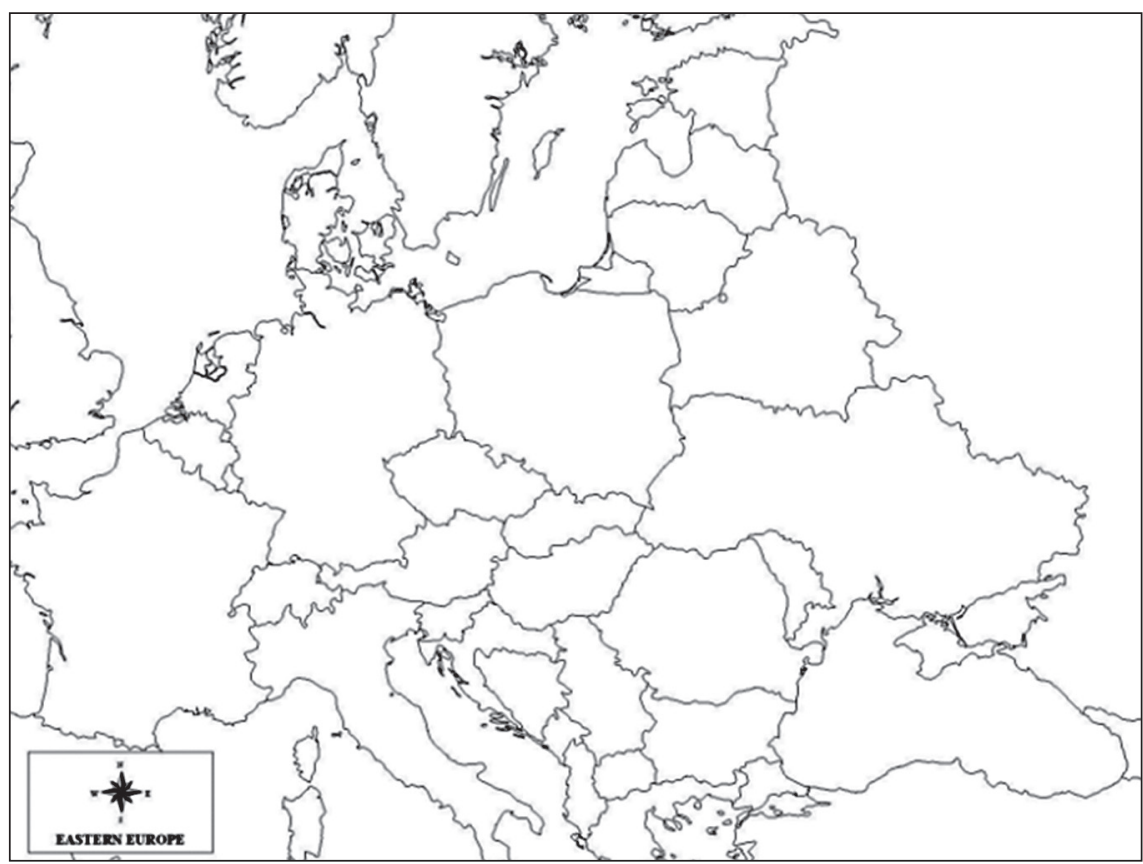

Źródło: http://tripmeter.me/eastern-europe-map-quiz.html/eastern-europe-map-quiz-countries-inspiringthroughout, 12 I 2016.

Mnogość przedstawionych propozycji, a także różnice między nimi, które bywają nieznaczne ilościowo, acz istotne jakościowo (kombinacje różniące się od siebie obecnością jednego, ale znaczącego dla całej koncepcji państwa), skłoniły nas do przyjęcia uproszczonego (trójelementowego) modelu delimitacji, zarazem nadającego artykułowi strukturę. Składa się nań po pierwsze „perspektywa pozytywna”, a więc obszary, które wchodzą w skład Europy Środkowej; po drugie „perspektywa negatywna”, czyli ziemie, które w granicach tych się nie mieszczą (w niektórych przypadkach klasyfikację tę nieco uszczegóławiamy, kiedy indziej zaś komentarz poświęcamy także tworom sąsiadującym z Europą Środkową - w przeświadczeniu, że lepsze zrozumienie problemu można uzyskać również na zasadzie negatywu, czyli dzięki analizie bytów, które znalazły się poza jej granicami); i po trzecie delimitacje, które współcześnie mogą uchodzić za - nazwijmy rzecz oględnie - specyficzne, a więc wymykające się znanym schematom (w czym zresztą może tkwić ich potencjat). W ramach podejścia odrębnego, choć nakładającego się na treści tworzące powyższy trójelementowy model, wyróżnimy trzy rodzaje propozycji: (a) te, które w mniejszym lub większym zakresie stanowią nawiązania do „tradycyjnych" ujęć, (b) te, które można traktować jako próbę redefinicji granic Europy Środkowej, ujmowanych z perspektywy drugiej dekady XXI w., (c) te, które jawią się jako pomysły „oryginalne”, tzn. nieposiadające umocowania w literaturze przedmiotu (przypadki te posłużą nam za impuls do refleksji nad typem wyobrażenia, które mogło skłonić 
autorów do takich właśnie delimitacji). Dodajmy, że w każdym z trzech przypadków ograniczyliśmy się do wybranych ilustracji, preferując te, które w naszym odczuciu odzwierciedlały głębszy zamysł autora mapy (mając zarazem świadomość, iż owa subiektywna selekcja mogła stać się przyczyną pominięcia innych oryginalnych ujęć).

Należy zaznaczyć, że twierdzenia te - jako agregaty analiz przeprowadzonych przez obu autorów - będą miały charakter hipotetyczny. Jak bowiem wskazaliśmy, do badanych skierowano tylko jedno pytanie, nie dysponujemy więc na ich temat żadnymi informacjami, w które moglibyśmy wpisać uzyskane odpowiedzi. Fakt ten ma poważne konsekwencje dla podejmowanych analiz i wyjaśnień, nie wiemy wszakże:

- czy respondent, proponując swoją delimitację, przyjął geograficzne, (geo)polityczne, czy kulturowe rozumienie pojęcia (albo jakąś kombinację tychże);

- czy poprawnie zidentyfikował wskazane przez siebie państwa (być może czasami wybór był przypadkowy);

- jak uzasadniłby swój wybór (czy w ogóle byłby w stanie), które to zastrzeżenie ma szczególną wagę w przypadku delimitacji mocno oryginalnych;

- czy przed badaniem w jego świadomości było w ogóle miejsce dla Europy Środkowej, czy może traktował ją jako część większej całości (np. Europy Wschodniej lub Europy Zachodniej), co oznaczałoby, że projekcja środkowoeuropejska została wywołana poleceniem badacza.

Ograniczenia te wzmacniają postulat, aby wartości badania doszukiwać się przede wszystkim w wielości i różnorodności zgłoszonych propozycji, które w przyszłości mogą posłużyć za punkt wyjścia do bardziej pogłębionych analiz, i tym samym aby przedstawione modele traktować w kategoriach eksploracji zagadnienia, w sensie metodologicznym zaś - jako pilotaż.

\section{EUROPA ŚRODKOWA - ELEMENTY KONSTYTUTYWNE}

Niniejszy punkt rozpocznijmy od wskazania ujęć „sztampowych” - takich, które mają utrwaloną pozycję w literaturze i w świadomości osób zajmujących się granicami Europy Środkowej. Przede wszystkim należy tu wskazać na pomysł utożsamiania tego kręgu wyłącznie z państwami tworzącymi Grupę Wyszehradzką, dodając, że propozycja ta nie pojawiła się tak licznie, jak można by sądzić po historii inicjatywy i wysiłkach zmierzających do stworzenia właśnie środkowoeuropejskiej platformy działania (np. na forum UE). Zarazem nie sposób oprzeć się pytaniu, czy nie mamy tu do czynienia z odzwierciedleniem pozycji, jaką inicjatywa V4 zajmuje w szerszej (przynajmniej europejskiej) świadomości; czy nie jest tak, że Grupa Wyszehradzka jest do pewnego stopnia rozpoznawalna wśród mieszkańców państw byt ów tworzących, poza tym jednak nie ma zbyt dużej mocy oddziaływania (a tym bardziej - „na wyłączność” czy jako konstytuanta Europy Środkowej)? Głosem w tej dyskusji może być fakt, że spośród państw ją tworzących jedynie Republika Czeska traktowana jest jako nieodzowny składnik Europy Środkowej; rzecz można ująć nawet mocniej: jeśli mamy do czynienia z Europą Środkową, to prawie na pewno pojawiają się w niej ziemie wchodzące obecnie w skład Republiki Czeskiej. 
Patrząc szerzej, warto zwrócić uwagę na mapę jednej z austriackich respondentek, która na południe od Polski odtworzyła granicę między Przedlitawią (Austria, Czechy, Słowenia), tu ujętą jako część Zachodu, a Zalitawią (Słowacja, Węgry, Chorwacja), która na tym odcinku (bez Zakarpacia i Siedmiogrodu) składa się na Europę Środkowąa ${ }^{12}$. Ta zaś tworzy tu (wraz z pozostałymi państwami byłej Jugosławii, Albanią i Grecją) byt jak gdyby przejściowy „na drodze ku Wschodowi”, konstytuowanemu m.in. przez republiki bałtyckie, Rumunię i Bułgarię. I chociaż, jak wspomnieliśmy, w ujęciu tym Republika Czeska stanowi komponent Zachodu, istotniejsze - jako część szerszego mechanizmu może być to, że kraj ten został przypisany do kategorii innej (w ujęciu wartościującym: wyższej) niż pozostałe elementy V4. Zmierzając do głębszego zrozumienia tego podejścia, raz jeszcze warto podkreślić, że wyszło ono spod pióra Austriaczki, a więc (prawdopodobnie) obywatelki państwa, które sąsiaduje z całą „czwórką” ziem w tym miejscu dla nas istotnych: Czechami, Słowenią, Słowacją i Węgrami (spośród których wszystkie oprócz Słowenii leżą w odległości nie większej niż $60 \mathrm{~km}$ od samego Wiednia).

Pozostając w duchu c.k. monarchii, wspomnijmy o nierzadkich propozycjach włączania w obręb Europy Środkowej Austrii. Zakładając, że działanie to odzwierciedla jakiś trwalszy i poważniejszy trend, warto zapytać hipotetycznie, czy nie zyskał on swoistego przedłużenia w wynikach wyborów parlamentarnych, które odbyły się nad Dunajem w październiku 2017 r. W nich to bowiem trzecie miejsce uzyskała sceptyczna wobec UE Wolnościowa Partia Austrii (Freiheitliche Partei Österreichs, FPÖ) ${ }^{13}$, której lider, Heinz-Christian Strache, pozytywnie wyrażał się o Grupie Wyszehradzkiej, a także czynił odwołania właśnie do monarchii austro-węgierskiej. Dla atmosfery tych wypowiedzi nie bez znaczenia może pozostawać również tzw. Trójkąt sławkowski czesko-słowacko-austriacka inicjatywa polityczna, zawiązana na początku 2015 r. Nawiązania te nie zmieniają jednak faktu bardziej o charakterze ilościowym: delimitacje Europy Środkowej odpowiadające choćby w przybliżeniu granicom monarchii austro-węgierskiej pojawiały się w naszym badaniu stosunkowo rzadko.

Należy zaznaczyć, że pozycja Austrii na wyobrażonej mapie Europy Środkowej wydaje się silniejsza niż Polski, w której wykluczaniu wyróżniają się zresztą właśnie respondenci austriaccy, podczas gdy badani Polacy dość chętnie włączają Austrię w skład interesującej nas części kontynentu. Do ustalenia pozostająźródła tej otwartości: czy może tu chodzić np. o kontekst historyczny (Austria jako fundament dawnej c.k. monarchii), czy środkowoeuropejskie (w sensie geograficznym) położenie Wiednia (na wschód od Pragi, w bliskości Bratysławy i Budapesztu), czy całego państwa?

12 Do tak pojmowanej Europy Środkowej respondentka zaliczyła także samą Polskę; my jednak pominęliśmy ją w powyższym opisie, ponieważ współcześnie jedynymi ziemiami RP, które dają się przyporządkować do wspomnianego podziału, są Galicja i Śląsk Cieszyński jako składowe Przedlitawii (tym samym pomijamy tu skrawki Spiszu, Orawy i innych fragmentów dzisiejszego pogranicza polsko-słowackiego, które były częścią Zalitawii).

13 Partia ta (której szefem do 2008 r. był izolowany w UE Jörg Haider) uzyskała 26-procentowe poparcie, nieznacznie ustępując socjaldemokratom (Sozialdemokratische Partei Österreichs, SPÖ), którzy zdobyli 26,9\% głosów, i zwycięskiej Austriackiej Partii Ludowej (Österreichische Volkspartei, ÖVP) z poparciem $31,5 \%$ głosujących. 
Warto również wspomnieć o delimitacji obejmującej, oprócz państw Grupy Wyszehradzkiej i Austrii, także Niemcy i Szwajcarię (co ciekawe, scenariusz ten nierzadko pojawiał się w odpowiedziach respondentów polskich). Propozycję tę można kojarzyć z koncepcją Mitteleuropy, aczkolwiek niekoniecznie w jej imperialnym (zaborczym) rozumieniu - wszak nie uwzględniano tu Ukrainy czy Białorusi, a sama Polska nierzadko była w tym gronie nieobecna.

Wśród zgłoszonych propozycji pojawiały się także konstelacje ściśle geograficzne (geometryczne), w których środek definiowano poprzez zbiór państw położonych centralnie na kontynencie. W takiej sytuacji interesujący nas krąg tworzyły np. Belgia, Holandia i Szwajcaria; pojawiała się także Dania i, wcale nierzadko, Włochy (przede wszystkim w deklaracjach samych Włochów). Być może tak wyrysowane mapy należy kojarzyć z założeniem, że dla części respondentów „Europa Środkowa” jest kategorią przede wszystkim geograficzną? Zauważmy przy okazji, że głosy te służyłyby za pars pro toto dylematu, który powracał nie tylko przy okazji delimitacji o charakterze geograficznym: niemożności stwierdzenia, czy zdaniem badanych zbiór zwany Europą Środkową jest - politycznie, społecznie, kulturowo - częścią Zachodu, Wschodu, czy też odrębnym bytem - właśnie Środkiem? Nie powinny nas przy tym zwieść liczne deklaracje, w których Skandynawia zaznaczana jest obok kategorii „Zachód”, wszak tutaj inaczej niż w przypadku Europy Środkowej - dylematów jest dużo mniej.

\section{POZA GRANICAMI EUROPY ŚRODKOWEJ}

Punkt syntetyzujący opis ziem, które umieszczano poza Europą Środkową, zacznijmy od stwierdzenia, że nie interesowały nas propozycje wyraźnie odbiegające od tego, z czym Europę Środkową zwykło się kojarzyć. Dlatego nie analizujemy tu sugestii „oczywistych", typu wykluczenie Rosji, Hiszpanii, Portugalii czy Wielkiej Brytanii; tego typu delimitacjom - w pewien sposób intrygującym w swej oryginalności - poświęcamy kolejny punkt artykułu.

Pierwsza kwestia powiązana jest z poprzednim wątkiem - geografią. Choć nie brakowało respondentów, którzy państwa byłej Jugosławii (lub ich część) włączali do Europy Środkowej, w tym miejscu bardziej interesujące są głosy, które poza jej ramami pozostawiały Bałkany. Co więcej, kategoria ta - jeśli już wystąpiła na mapie - zawsze oznaczała pojawienie się odrębnego bytu, którego sensem istnienia wydaje się kultura, nie zaś geografia; niejednokrotnie bowiem opisywano kontynent przy pomocy kwalifikacji geograficznych (północ, południe, wschód, zachód), listę tę uzupełniając o słowo „Bałkany” ${ }^{14}$.W tym kontekście czasami pojawia się pytanie o to, które kraje tworzą Bałkany w owym kulturowym, a zarazem mocno deprecjonującym znaczeniu, swego czasu przybliżonym przez Marię Todorovą ${ }^{15}$. Zagadnieniem spornym, które pojawiło

14 Gwoli ścisłości przypomnijmy, że niektórzy badani posługiwali się także - jako kulturowo odrębną kategorią „Skandynawia”, jednak liczba tego typu ujęć była niewielka, a ciężar gatunkowy - inny.

15 M. Todorova, Batkany wyobrażone, przeł. P. Szymor, M. Budzińska, Wołowiec 2008, s. 19-20. 
się także w naszych badaniach, jest przede wszystkim Chorwacja, rzadziej Słowenia, włączana do tego grona zapewne z racji swego członkostwa w Jugosławii, być może również, omyłkowo, ze względu na swój niewielki rozmiar.

Wątkiem łączącym się z „kwestią bałkańską” jest pytanie o Rumunię, która przeważnie nie pojawiała się jako część Europy Środkowej. Co ciekawe, zdarzały się sytuacje, gdy na interesującą nas część kontynentu składały się m.in. Bułgaria, Grecja i Albania, ale już nie Rumunia. Z odpowiedzi badanych można raczej wywnioskować, że państwo to należy do Bałkanów, Wschodu lub do niczego. Co ciekawe, ostatnia z tych opcji lokuje się blisko stanowiska, które proponuje popularny rumuński historyk Lucian Boia: akcentując krzyżowanie się na obszarze swego kraju (a ściślej - jego regionów) różnych wpływów kulturowych, stwierdził on, że Rumunia jest zatem jednocześnie batkańska, wschodnia iśrodkowoeuropejska, nie przynależąc w petni do żadnej z tych kategorii - skadinąd dośćsztucznych ${ }^{16}$.

Interesujący jest także casus republik bałtyckich. Granice zaproponowane przez badanych bardzo wyraźnie wskazują, że państwa te należą do Wschodu (ewentualnie, choć dużo rzadziej, do Skandynawii). Co ciekawe, nierzadko proponowano szerokie ujęcie Europy Środkowej - kraje V4, państwa byłej Jugosławii plus Grecja, Albania, Bułgaria czy nawet Rumunia - w którym jednak zabrakło miejsca dla Litwy, Łotwy i Estonii. Traktowanie tych republik jako części Wschodu zdaje się także sygnałem na temat odrzucenia ujęcia, w myśl którego czynnikiem konstytutywnym dla Europy Środkowej jest transformacyjny postkomunizm i członkostwo w UE w ramach „nowej Europy”. Taki wzór myślenia ujawnia się również w projekcjach respondentów polskich, choć - mając na względzie wspólną historię - można byłoby oczekiwać, że akurat oni będą skłonni wyłączać z tego jednorodnego zbioru przynajmniej Litwę. Brak takich wskazań można więc interpretować jako symboliczne odrzucenie przez tych respondentów dziedzictwa Rzeczypospolitej Obojga Narodów ${ }^{17}$. Zdiagnozowane przez nas ujęcie oznacza, że akcesja do UE nie odegrała szczególnej roli w symbolicznym „wyjęciu” republik bałtyckich z kategorii Pribattiki; dodajmy, że w aspekcie geopolitycznym mogłoby to w przyszłości skutkować traktowaniem owych państw jako nieformalnej rosyjskiej strefy wpływów - ze wszystkimi tego (negatywnymi) konsekwencjami.

Mniej zaskakujące jest umieszczenie w ramach Wschodu Ukrainy i Białorusi wśród ogółu respondentów tylko jedna osoba przypisała do Europy Środkowej zachodnie fragmenty obu państw. Obserwacja ta wydaje się wskazywać, że dla badanych nie istnieje słynny „uskok cywilizacyjny” Samuela P. Huntingtona - linia stanowiąca wschodnią granicę cywilizacji zachodniej - w tej części Europy pokrywający się mniej więcej ze wschodnią granicą II RP. Dodajmy, że w skład Europy Środkowej nie włączano także Siedmiogrodu czy Wojwodiny - innych regionów, które amerykański politolog

16 L. Boia, Dlaczego Rumunia jest inna?, Kraków 2016, s. 14.

17 Fakt powszechnego traktowania Litwy jako części Wschodu zaobserwowano także w innych badaniach. Por. M. Dębicki, J. Makaro, Postawy wobec Litwy i Litwinów na przyktadzie wroctawian, Kraków 2016, s. 183-186. 
kojarzył z Zachodem ${ }^{18}$. Przyjęta metodologia nie uprawnia nas do ekstrapolacji wyników z próby na populację, jednak zważywszy na niemałą reprezentację respondentów polskich w badaniu, choćby tytułem refleksji sformułowanej na marginesie zapytajmy: czy pozostawienie poza granicami Europy Środkowej Ukrainy (przynajmniej zachodniej) oraz Litwy (przynajmniej południowo-wschodniej) nie jest wskaźnikiem słabnącego zainteresowania Polaków swymi dawnymi Kresami?

$\mathrm{Z}$ polskiego punktu widzenia intrygujący może być również sygnalizowany przez nas wcześniej fakt wyłączania z Europy Środkowej samej Polski. Zarazem jednak nie można tu pozostać obojętnym na okoliczności, które do pewnego stopnia uzasadniałyby takie podejście - relatywnie duży rozmiar państwa, ograniczenie doświadczeń egzystencji w ramach monarchii austro-węgierskiej (jako państwa środkowoeuropejskiego par excellence) do stosunkowo niewielkiego fragmentu dzisiejszej Polski (Galicji i Śląska Cieszyńskiego) czy jej geograficzne wysunięcie ku północy. W tym kontekście należy wspomnieć także o obszarze ujętym na mapie przedłożonej respondentom, na której ten ostatni czynnik zyskiwał dodatkowe podbudowanie w dość ograniczonej obecności Skandynawii, skutkiem czego Polska wydawała się państwem bardziej północnym, niż jest w rzeczywistości. Za wyłączaniem jej z regionu Europy Środkowej przemawiać może także to, że największa świetność państwa polskiego (podobnie zresztą jak węgierskiego) związana jest z jego orientalizacją, wychyleniem ku Wschodowi, otwartością na Wschód. Polska Jagiellonów to państwo rozpościerające się kilkaset kilometrów na Wschód od obecnych granic Rzeczypospolitej, którą propaganda powojenna ochrzciła mianem Polski Piastowskiej. Nie da się ukryć, że I Rzeczpospolita w sensie kulturowym, zważywszy na strukturę etniczną, wyznaniową, ale też na interesy geopolityczne, była państwem Wschodu, prowadzącym aktywną politykę wobec Rosji oraz Turcji i zmagającym się z nimi o ziemie mieszczące się na wschodnich rubieżach Europy $^{19}$. Jeśli traktować Polskę jako całość w obecnych granicach administracyjnych, można uznać, że państwo to należy do Europy jako takiej i na swój sposób wymyka się podziałom na Wschód, Zachód i Środek. W pewnym stopniu może to być podyktowane traumą porozbiorową z okresu XIX w., gdy poszczególne części ziem polskich znalazły się w granicach państw różniących się od siebie pod względem cywilizacyjnym. Prusy były bowiem reprezentantem militarystycznej cywilizacji germańskiej, Rosja reprezentowała cywilizację bizantyjską z kultem jednostki i samodzierżawiem, Austria wreszcie, jakkolwiek z fundamentów germańska, bliska była kręgowi cywilizacji romańskiej z silnymi wpływami Słowiańszczyzny.

Wspomniany „czynnik skandynawski” mógł być odpowiedzialny także za to, że w uzyskanych delimitacjach Europy Środkowej brakuje miejsca dla Finlandii (jeszcze w okresie międzywojennym zaliczano ją do państw Międzymorza), aczkolwiek okoliczności tej nie należy przeceniać w obliczu innych niż w przypadku Europy Środkowej

18 S.P. Huntington, Zderzenie cywilizacji i nowy ksztatt tadu światowego, przeł. H. Jankowska, Warszawa 2000, s. 231, Spectrum.

19 Zob. R. Zenderowski, Europa Środkowa jako "ucieczka przed Wschodem” czy "pomost” między Wschodem i Zachodem?, [w:] Europa Środkowa. Wspólnota czy zbiorowość?, red. tenże, Wrocław 2004, s. 3648; tenże, Pomiędzy Wschodem a Zachodem?, „Przegląd Zachodni” 2004, nr 3, s. 3-19. 
losów politycznych tego kraju po 1945 r. Zapewne jeszcze inaczej sprawa miała się z niemal całkowitą nieobecnością w granicach interesującego nas kręgu byłej Niemieckiej Republiki Demokratycznej. Tutaj przypuszczalnie należy się liczyć z efektem najnowszej historii - faktem, że od ponad ćwierćwiecza tereny NRD składają się na zjednoczone Niemcy. Jeśli wyjaśnienie to zyskałoby szerszą reprezentację empiryczną, mielibyśmy tu do czynienia z zanikiem (w świadomości masowej) znaczenia okoliczności, które Antoni Podraza potraktował jako konstytutywne dla względnie trwałego wyłączenia wschodniej części Niemiec z Europy Zachodniej ${ }^{20}$. Warto podkreślić, że rzeczone rozróżnienie zanika "na zewnątrz”, a więc poza Niemcami, jednak „wewnątrz”, czyli w Niemczech, podział na wschód i zachód nadal jest dość żywotny. Okoliczność ta zasadniczo nie zmienia jednak faktu, że we wspomnianej nieobecności NRD nie ma niczego dziwnego, zważywszy na to, iż przywołany badacz miał na myśli „historię długiego trwania", a więc czynnik dla wielu osób mocno abstrakcyjny.

W naszych badaniach w zasadzie nie zaobserwowaliśmy wzoru granic Europy Środkowej obejmującej te państwa (i tylko te), które przystąpiły do UE w latach 2004-2013 (z pominięciem Cypru i Malty, a nawet ewentualnie republik bałtyckich); podobnie nie pojawił się też model „państwa między Rosją a Niemcami”. Może to być sygnałem w kwestii relatywnie małej wagi, jaką respondenci przypisywali owym akcesjom, ale równie dobrze rzecz może dotyczyć wyobrażonego przez nich znaczącego wewnętrznego zróżnicowania tego zbioru, które to przeświadczenie przeważyłoby nad wspólnym mianownikiem - akcesją do UE. Od strony metodologicznej dodajmy, że być może głównym czynnikiem była niewielka liczebność respondentów z państw byłego ZSRR; tymczasem - zważywszy na fakt, iż w Związku Radzieckim termin „Europa Srodkowa” był objęty cenzurą - można byłoby tu liczyć na interesujące projekcje ze strony obywateli tych państw.

Odmianą powyższego podejścia jest stanowisko (zaprezentowane przez jedną osobę), że coś takiego jak Europa Środkowa w szeroko pojętym sensie kulturowym (społecznym, politycznym itd.) nie istnieje - są tylko Zachód i Wschód, który tworzony jest także przez Środek. Z jednej strony podejście to wydaje się wyrastać z geopolitycznego wzoru sprzed 1989 r. - podziału Europy na dwa obozy, z drugiej jednak może ono być, raz jeszcze poniekąd na wzór „historii długiego trwania”, efektem wzięcia bieżącego, transformacyjnego ćwierćwiecza w swoisty nawias - i tym samym prefiguracją tego, co może się znów przydarzyć...

\section{DELIMITACYJNE OSOBLIWOŚCI}

Oddalając potencjalny zarzut, że powyższy śródtytuł grzeszy protekcjonizmem wobec autorów omówionych tu delimitacji, na wstępie należy podkreślić, że w dziejach dyskusji na temat granic interesującego nas kręgu kulturowego pojawiały się propozycje,

20 A. Podraza, Central Europe as a Historical Region, [w:] Central Europe Between East and West, red. J. Kłoczowski, Lublin 2005, s. 44. 
które ze współczesnej perspektywy wydają się całkowicie niedorzeczne i kuriozalne, a swego czasu trafiły na poważne łamy ${ }^{21}$. Oznacza to, że śródtytułowe „osobliwości” tu odnoszące się nie tylko do granic Europy Środkowej, lecz także do bytów sąsiednich - należy rozumieć jako propozycje, które współcześnie wydają się nie mieć zbyt silnego umocowania w tradycji czy literaturze przedmiotu, ale w przyszłości - kto wie...

Zacznijmy od ujęcia, które zasadzało się na wyłączeniu z Europy Środkowej Węgier i włączeniu ich w obręb Bałkanów. Delimitacja taka wyszła spod pióra m.in. respondenta słowackiego, w czym - historycznie rzecz biorąc - można doszukiwać się zamiaru odrzucenia Węgier jako czegoś „swojego” (przynajmniej w sensie regionalnym - jako pewnej części kontynentu ${ }^{22}$. Zważywszy na fakt, że ziemie nad Balatonem zostały włączone w skład Bałkanów także przez Serba, Turka, Polaka i Węgra, wypada zaznaczyć, że problem jawi się jako bardziej złożony. Pomijając respondentów tureckich, którzy w poczet państw bałkańskich zaliczali samą Turcję, a także inne ziemie wchodzące niegdyś w skład Imperium Osmańskiego (np. Mołdawię), warto zauważyć, że z historyczno-kulturowego punktu widzenia Węgry wydają się mieć sporo wspólnego z Rumunią i północno-zachodnim fragmentem byłej Jugosławii ${ }^{23}$, a jednocześnie w pewnych aspektach różnić się od Czech czy Polski.

Na uwagę zasługuje także propozycja respondenta z Polski (!), który do Europy Środkowej zaliczył zachodnią część swego kraju, wschodnią zaś - do Europy Wschodniej (granica została poprowadzona mniej więcej wzdłuż Wisły). Dodajmy, że nie był to jedyny przykład takiego rozczłonkowania Rzeczypospolitej i że podobnie (kilkakrotnie) postąpiono także ze Słowacją czy Węgrami, jak również z dawną NRD, którą w przeciwieństwie do dawnej RFN - przypisano do Europy Środkowej.

Warto również wskazać na mapę, której autor wykluczył Rosję z granic Europy Wschodniej. Jak się wydaje, kryterium delimitacyjnym była tu przynależność tego państwa do odrębnej cywilizacji, konstytuowanej nie na bazie samego tylko prawosławia i języka, lecz czegoś więcej. Nie wnikając w te kwestie, warto zauważyć - w duchu wyrastającym z natury przedstawianych tu propozycji - że usunięcie Rosji w ogóle poza Europę, aczkolwiek bezzasadne geograficznie, przynajmniej częściowo uwolniłoby kategorię „Europa Wschodnia” od obciążających ją negatywnych skojarzeń z samym Wschodem.

Na koniec zostawmy ślad po propozycjach, których nie podejmujemy się komentować, jednak wydają się warte utrwalenia. I tak poza mapą Europy Środkowej pozostaje

21 Zob. M. Buchowski, I. Kobłon, Od „Mitteleuropy” do Europy Środkowej: zarys dziejów idei, „Sprawy Narodowościowe. Seria Nowa” 2001, z. 19, s. 12.

22 Przy okazji warto wyrazić przypuszczenie, że respondent ów prawdopodobnie miał na myśli współczesność, wszak ulokowanie Madziarów w obrębie Bałkanów w wymiarze historycznym oznaczałoby taki sam los w odniesieniu do ziem dzisiejszej Słowacji. Zarazem jeśli podejście to zyskałoby pod Tatrami szerszą reprezentację, można byłoby zastanawiać się na społecznym wymiarem spoistości w łonie Grupy Wyszehradzkiej, a także samej Europy Środkowej jako wspólnej płaszczyzny.

23 Do rangi nieledwie anegdotycznej urasta fakt, że w Segedynie - węgierskim mieście położonym niedaleko granicy z Serbią - można kupić przysmaki kuchni bałkańskiej (np. burek), a także to, iż na półkach księgarskich przewodniki turystyczne po Węgrzech bywają umieszczane w dziale „Bałkany”. 
Polska, w obrębie zaś - Rumunia; nie ma Polski i Czech, są natomiast m.in. Słowacja, Węgry, Austria, Słowenia, Szwajcaria, Chorwacja, a nawet Bośnia i Hercegowina; zgłoszono też mapę (autorstwa respondenta tureckiego), na której Europę Środkową tworzy tylko jeden kraj - Austria. Dodajmy, że pojawiły się także delimitacje, których oryginalność graniczy z geograficzną ignorancją (Białoruś jako część Bałkanów).

\section{ZAKOŃCZENIE}

Na koniec powróćmy do tego, że w naszych badaniach niemal niezauważalne były delimitacje odwołujące się do postkomunizmu jako wspólnego mianownika państw składających się na Europę Środkową. W momencie upadku owego systemu, rzecz jasna, trudno było zakładać, że społeczeństwa, które przez kilkadziesiąt lat należały do bloku socjalistycznego (chodzi o zachodnią część ZSRR, jego satelitów oraz Jugosławię), pomimo zasadniczych różnic między nimi, utworzą zbiór spajany wyłącznie (lub przede wszystkim) pragnieniem integracji z Europą Zachodnią; równocześnie jednak trudno było sądzić, że w obrębie tego grona możliwe będzie wyróżnienie kilku typów, wewnętrznie również niejednolitych. Przyglądając się im, zauważmy, że obecnie, na gruncie przede wszystkim politycznym, jedynie co najwyżej dwa z nich (I i ewentualnie III) uważane są za konstytuantę Europy Środkowej.

- typ I:Polska, Republika Czeska, Słowacja i Węgry, a więc państwa, które utworzyły Grupę Wyszehradzką i są najczęściej utożsamiane z Europą Środkową;

- typ II: Litwa, Łotwa i Estonia, które z jednej strony pragnęły wyraźnie odróżnić się od obszaru poradzieckiego, przede wszystkim od samej Rosji, z drugiej zaś - pozostały w niejakim zawieszeniu pomiędzy różnymi kręgami kulturowymi (Europa Środkowa, Wschód, Skandynawia);

- typ III: Słowenia, jako część byłej Jugosławii, od dziedzictwa której kraj ten jednak szybko się odciąt, a także mająca podobne ambicje, ale i swą specyfikę, Chorwacja;

- typ IV: Bułgaria, którą sporo łączy z Serbią i Macedonią, a która przystępując (wraz z Rumunią) do UE w 2007 r., „rozcięła” Bałkany na zachodnie i wschodnie (które to pęknięcie sześć lat później nieco złagodziła akcesja Chorwacji);

- typ V: państwa pozostałej części byłej Jugosławii (pytanie o Kosowo), ewentualnie wraz z Albanią;

- typ VI: Rumunia, która będąc rozdarta historycznie i kulturowo, w pełni nie przynależy ani do Europy Środkowej, ani do Bałkanów, ani do Wschodu;

- typ VII: Ukraina, Białoruś i Mołdawia, które w poszczególnych aspektach są od siebie dość różne, jednak wydają się złączone głęboką zależnością od Rosji, skutecznie hamującą - w połączeniu z innymi czynnikami - możliwość integracji tych państw z UE.

Nawet bez dodawania Finlandii, Niemiec, Austrii czy Grecji - a więc państw, które przed 1989 r. podążały odmienną drogą niż Europa Środkowa i bywały włączane do tego zbioru (w różnych momentach różnie zresztą nazywanego) - $\mathrm{z}$ łatwością dostrzeżemy pojemność interesującej nas kategorii. Równocześnie trudno nie dostrzec, 
że zasygnalizowane powyżej zróżnicowanie państw, które po 1989 r. wydobywały się z oków socjalizmu, skłania do postawienia pytania, czy nie jest tak, że jakaś forma trwałej jedności na gruncie geopolitycznym jest możliwa w Europie Środkowej tylko pod wpływem zaprowadzonej z zewnątrz urawnitowki. Owszem, dla kręgu tego wspólny mianownik (w niektórych sferach dość szeroki) odnajdujemy na gruncie kultury - tyle że trudno założyć, iż czynnik ten był szczególnie znaczący dla naszych respondentów.

Ograniczenia metodologiczne, związane z niewielką i mocno zróżnicowaną liczbą reprezentantów poszczególnych kategorii obywatelstwa, a także z przyjętą perspektywą badań jakościowych, nie pozwoliły na wykorzystanie spodziewanego potencjału eksplanacyjnego tej zmiennej. Zaznaczmy również, że lepszemu zrozumieniu zgłoszonych propozycji z pewnością przysłużyłoby się pogłębienie problemu granic Europy Środkowej w formie wywiadu (np. wspomaganego mapą), który mógłby pomóc odkryć przed badaczem motywy wyznaczenia poszczególnych delimitacji, a także oddzielić te, których źródło bije raczej w geograficznej niewiedzy badanych niż w oryginalności spojrzenia.

\section{BIBLIOGRAFIA}

Anzabl der Ausländer in Österreichnach den zehnwichtigstenStaatsangehörigkeiten am 1. Januar 2020, [online] https://de.statista.com/statistik/daten/studie/293019/umfrage/auslaenderin-oesterreich-nach-staatsangehoerigkeit/.

Boia L., Dlaczego Rumunia jest inna?, przeł. J. Kornaś-Warwas, Kraków 2016, Biblioteka Europy Środka.

Buchowski M., Kobłon I., Od „Mitteleuropy” do Europy Środkowej: zarys dziejów idei, „Sprawy Narodowościowe. Seria Nowa” 2011, z. 19.

Census 2011 Wien. Ergebnisse zur Bevölkerung aus der Registerzählung, [online] https:// www.statistik.at/web_de/dynamic/statistiken/bevoelkerung/volkszaehlungen_register zaehlungen_abgestimmte_erwerbsstatistik/publdetail $? \mathrm{id}=22 \&$ listid $=22 \&$ detail $=671$.

Czakon D., Od imigracji do integracji po status mniejszości narodowej. Przyktad Polaków w Austrii, „Studia Migracyjne - Przegląd Polonijny” 2011, z. 2.

Dębicki M., Makaro J., Postawy wobec Litwy i Litwinów na przyktadzie wroctawian, Kraków 2016.

Findl P., Helczmanovszki H., The Population of Austria. Austrian Academy of Sciences, Institute of Demography. 1974 World Population Year, Vienna 1977.

Godlewska E., Status prawny mniejszości narodowych w Austrii na przetomie XX i XXI wieku, „Forum Politologiczne” 2007, $\mathrm{nr} 5$.

Gruszczyński L.A., Kwestionariusze w socjologii. Budowa narzędzi do badań surveyowych, Katowice 1999, Skrypty Uniwersytetu Ślaskiego, nr 551.

Huntington S.P., Zderzenie cywilizacji i nowy kształt tadu światowego, przeł. H. Jankowska, Warszawa 2000, Spectrum.

Jandl M., Kraler A., Austria: A Country of Immigration?, Migration Policy Institute, [online] https://www.migrationpolicy.org/article/austria-country-immigration. 
Monitoring Integration Diversity Vienna 2009-2011. Short version, [online] https://www.wien. gv.at/menschen/integration/pdf/monitoring-2012-short.pdf.

Podraza A., Central Europe as a Historical Region, [w:] Central Europe Between East and West, red. J. Kłoczowski, Lublin 2005.

Romejko A., Przemiany austriackiej tożsamości narodowej, [w:] Procesy migracyjne w kontekście przemian kulturowo-cywilizacyjnych, red. E. Polak, J. Leska-Ślęzak, Pelplin 2007.

Shepherd W.R., Distribution of Races in Austria-Hungary, Wien 1911.

Statistisches Jahrbuch der Stadt Wien, Wien 2013.

Szczerek Z., Międzymorze. Podróże przez prawdziwa i wyobrażoną Europę Środkową, Warszawa-Wołowiec 2017.

Todorova M., Batkany wyobrażone, przeł. P. Szymor, M. Budzińska, Wołowiec 2008.

Volkszählungvom 31. Dezember 1910, Geographischer Atlas zur Vaterlandskunde an der österreichischen Mittelschulen, Wien 1911.

Zenderowski R., Europa Środkowa jako „ucieczka przed Wschodem” czy „pomost” między Wschodem i Zachodem?, [w:] Europa Środkowa. Wspólnota czy zbiorowość?, red. R. Zenderowski, Wrocław 2004.

Zenderowski R., Pomiędzy Wschodem a Zachodem?, „Przegląd Zachodni” 2004, nr 3.

Dr hab. Marcin DĘBICKI - adiunkt w Zakładzie Socjologii Pogranicza Instytutu Socjologii Uniwersytetu Wrocławskiego. Zajmuje się społecznym obliczem Europy Środkowej, ze szczególnym uwzględnieniem polskich sąsiedztw, w tym pograniczy; zagadnieniom tym poświęcił kilkadziesiąt artykułów naukowych i kilka esejów. Autor monografii: Stereotypy Czechów wobec Polaków na pograniczu. Regionalne zróżnicowanie oraz determinanty stanu rzeczy (2010), Postawy Polaków wobec Litwy i Litwinów na przyktadzie wroctawian (2016, wraz z Julitą Makaro), Stowo i terytorium. Eseje o Europie Środkowej (2017, wraz z Martą Cobel-Tokarską). Wspólnie z Julitą Makaro był współorganizatorem cyklu konferencji naukowych i współredaktorem siedmiu tomów Sasiedztwa III RP (2012-2020).

Prof. dr hab. Radosław ZENDEROWSKI - politolog i socjolog, kierownik Katedry Stosunków Międzynarodowych i Studiów Europejskich Instytutu Nauk o Polityce i Administracji Uniwersytetu Kardynała Stefana Wyszyńskiego w Warszawie; członek Rady Naukowej Polskiego Towarzystwa Studiów Europejskich (2014-2015; 2019-2023). Zajmuje się badawczo problematyką: tożsamości ponadnarodowej (Europa Środkowa); granic i pograniczy, miast transgranicznych; etnicznego separatyzmu i związków nacjonalizmu z religią (etnicyzacji religii i sakralizacji narodu), znaczenia czynnika religijnego w polityce; polityki etnicznej państw Europy Środkowo-Wschodniej; dyplomacji publicznej i obywatelskiej w regionach trans/przygranicznych. Propagator turystyki kulturowej i religijnej (miłośnik Europy Środkowej i Bałkanów), uzależniony od kolei żelaznych. Mieszka naprzemiennie w Cieszynie i Warszawie. Wykłada w Warszawie, Ostrawie i Wiedniu. 